\title{
PICTA IMAGO MARTYRIS: OBRAZY JAKO ŹRÓDLO INSPIRACJI PERISTEPHANON IX I XI PRUDENCJUSZA
}

Jest powszechnie znanym faktem, że klasyczna literatura grecka i rzymska wielokrotnie odwoływała się do motywów sztuki jako do źródła inspiracji. Bez wattpienia niektóre sceny w wielkich utworach epickich, jak np. w Eneidzie Wergiliusza czy w Metamorfozach Owidiusza powstały pod wplywem dzieł sztuki obrazów, rzeźb czy płaskorzeźb. Opisy te, zwane po grecku ekphráseis ${ }^{1}$, po łacinie descriptiones, należały do systemu szkolnych ćwiczeń retorycznych - tzw. gr. progymnásmata ${ }^{2}$ (łac. praeexercitamina). Szkoła retoryczna wdrażała uczniów do tego rodzaju opisów, które były elementem wspólnym dla wszystkich trzech rodzajów wymowy: genus deliberativum (gr. génos symbouleutkikón), genus iudiciale (gr. génos dikanikón) i genus demonstrativum (gr. génos epideiktikón) ${ }^{3}$.

Studia retoryczne, które przygotowały Prudencjusza do przyszłego zawodu obrońcy sądowego, wyrobiły $\mathrm{w}$ nim $\mathrm{z}$ pewnością umiejętność komponowania owych ekphráseis. Zastosowanie ich przez niego w poezji było już tylko kwestia wyboru właściwych środków wyrazu artystycznego. Typ uprawianej przez Prudencjusza twórczości stwarzał szerokie możliwości posługiwania się ekphráseis w różnych funkcjach strukturalnych. Jest to szczególnie widoczne w takich utworach Prudencjusza, jak Psychomachia i Peristephanon, gdzie znajdujemy stosunkowo liczne partie opisowe, z których część można uznać za ekphráseis. W dwóch utworach z cyklu poetyckiego pt. Peristephanon: IX (Passio Cassiani Forocorneliensis) i XI (Ad Valerianum episcopum de passione Hippolyti beatissimi martyris), ekphráseis obrazów, na których zostały przedstawione sceny męczeństwa, stały się, jak można przypuszczać, źródłem inspiracji tematycznej. Przedmiotem poniższego szkicu będzie właśnie analiza tych obydwu passiones $\mathrm{w}$ aspekcie funkcji strukturalnej występujących w nich ekphráseis.

'Por. D. F ow le r, Narrate and Describe: Problem of Ekphrasis, „Journal of Roman Studies" 8(1991), s. 25 n.; por. także Z i o m e k, Retoryka opisowa, Wrocław [i in.] 1990, s. 91, 137, A. W. H a l s h a l, Beschreibung, [w:] Historisches Wörterbuch der Rhetorik, Tübingen 1992, szp. 1496 n.

${ }^{2}$ Por. G. A. K e n n e dy, A New History of Classical Rhetoric, Princeton 1994, s. 202-207 ; zob. takze M. K o rolk o, Sztuka retoryki. Przewodnik encyklopedyczny, Warszawa 1990, s. 140 n., 167 n.

${ }^{3}$ Por. R. V ol k m a n n, Rhetorik der Griechen und Römer, München 1901, przekł. pol. Warszawa 1995 , s. 119 n. 
Zacznijmy od Peristephanon $I X$, którego tematem jest męczeństwo św. Kasjana w Forum Cornelii ${ }^{4}$. Narrator utworu opowiada tu o swoim przybyciu do tego miasta w drodze do Rzymu i odwiedzeniu - prawdopodobnie w miejscowym kościele - grobu św. Kasjana, przy którym rozpamiętywał swoje grzechy i nieszczęścia życiowe (mea vulnera et omnes/ vitae labores ac dolorum acumina, w. 7-8). W czasie owego rachunku sumienia i żalu za grzechy narrator spostrzegł wiszący w górze obraz (przypuszczalnie fresk) przedstawiający męczeństwo św. Kasjana:

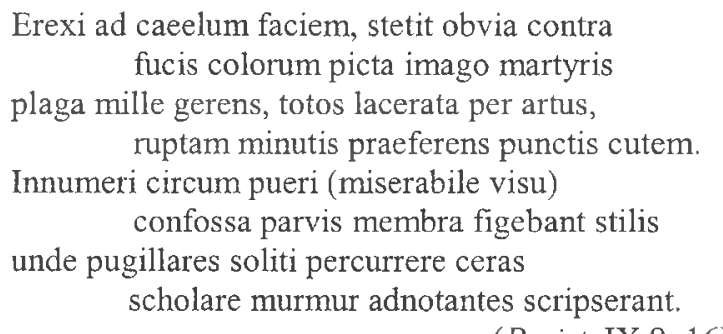

$(\text { Perist. IX 9-16) })^{5}$

Opis owej sceny jest stosunkowo zwięzły, przynosi jedynie szkic czy zarys tragedii, jaka niegdyś rozegrała się w Forum Cornelii. Nieznany malarz uwidocznił tu w kolorach poznaczone mnóstwem ran ciało męczennika oraz otaczający tłum chłopców, którzy kłują je ostrymi rylcami używanymi zwykle do pisania na woskowych tabliczkach.

Kolejny element kompozycyjny Peristephanon $I X$ stanowi opowiadanie kościelnego (aedituus), który na prośbę narratora relacjonuje historię męczeństwa św. Kasjana (w. 17-98), nawiązując do znajdującego się nad grobowcem obrazu (fresku), który jego zdaniem odpowiada rzeczywistym wydarzeniom ${ }^{6}$ :

Quod prispicis, hospes, non est inanis aut anilis fabula.

Historiam pictura refert, quae tradita libris veram vetusti temporis monstrat fidem.

(Perist. IX 17-20)

Kościelny, który pełni w tym utworze funkcję dodatkowego narratora, powołuje się w swoim opowiadaniu na „księgi" (libri) opisujące dzieje owego męczeństwa. Idzie tu zapewne o nie zachowane do naszych czasów Acta martyrum, które rzekomo zawierały wiarygodne informacje na temat św. Kasjana (non est inanis aut anilis fabula). Obraz ma więc być wedhug kościelnego powtórzeniem zapisu w owych „księgach" (Historiam pictura refert, quae tradita libris), a jed-

${ }^{4}$ Obecnie Imola w środkowej Italii; imię Kasjana znajduje się w Martyrolgium Vetustissimum, PL 30,47; rozwój kultu św. Kasjana datuje się na poł. V wieku; zob. także M. L a v a re n n e, Passion de saint Cassien de Forum Cornelii, [w:] Prudence. Le livre de couronnes, Paris 1963, s. 109-111; J. D u c hn i e w s k i, Kasjan, [w:] Encyklopedia katolicka, t. VIII, Lublin 2000 , szp. $245 \mathrm{n}$.

${ }^{5}$ Wszystkie cytaty z Peristephanon wg wydania Aurelii Prudentii Clementis Carmina, ed. M. P. Cunningham, Turnholt 1966.

${ }^{6}$ A.-M. P a $1 \mathrm{me} \mathrm{r}$, Prudentius on the Martyrs, Oxford 1989, s. 113 dostrzega w tym utworze, podobnie jak w Peristephanon XI, wpływ tendencji aitilogicznej zbliżonej do Fasti Owidiusza. 
nocześnie ukazywać prawdę o owych odległych wydarzeniach (veram vetusti temporis monstrat fidem). Na zakończenie swego opowiadania kościelny dodaje następujący komentarz odnoszący się do obrazu: Haec sunt quae liquidis expressa coloribus, hospes (w. 93). Wyjaśniene to wraz $\mathrm{z}$ uwagami na temat obrazu w wierszach 17-20 tworzy swojego rodzaju ramę narracyjną dla przedstawienia wydarzeń związanych z męczeństwem św. Kasjana.

Spróbujmy jednak przyglądnąć się nieco dokładniej owym wydarzeniom, które składają się na akcję opowiadania kościelnego o śmierci św. Kasjana. Pierwszy segment narracji zawiera informację o działalności nauczycielskiej św. Kasjana, o kierowaniu przez niego szkoła, w której kształcił swoich uczniów w tachygrafii (w. 21-28). Kolejna część przynosi relację o śledztwie prowadzonym w jego sprawie przez urzędnika rzymskiego i zapowiedź wydania Kasjana na pastwę jego uczniów (w. 29-42). Trzeci człon stanowi opis samych tortur zadawanych nieszczęsnemu nauczycielowi przez okrutnych uczniów drwiących z jego męki (w. 43-84). Końcowa partia utworu jest opowiadaniem o śmierci męczennika, nad którym zlitował się sam Chrystus, kładąc kres jego cierpieniom (w. 85-92).

Porównanie sceny ukazanej na obrazie z opisem męczeństwa św. Kasjana w opowiadaniu kościelnego prowadzi do dosyć zaskakującej konkluzji. Otóż to stosunkowo obszerne opowiadanie nie przynosi w istocie wielu nowych informacji na temat męczeństwa Kasjana w stosunku do szkicowo nakreślonej ékphrasis obrazu. W gruncie rzeczy scena męczeńskiej śmierci św. Kasjana przedstawiona na obrazie anonimowego artysty została w opowiadaniu kościelnego poszerzona zaledwie o kilka nowych elementów. Należą tu mianowicie nastepujące informacje: św. Kasjan był nie lubianym przez uczniów nauczycielem tachygrafii (w. 2324), w okresie prześladowania chrześcijaństwa został oskarżony o odmowę złożenia ofiar bóstwom pogańskim i postawiony przed urzędnikiem sądowym, który go wydał na tortury (w. 29-42), uczniowie znęcali się nad swoim nauczycielem i szydzili z niego.

Wydaje się, że zdobycie takich informacji nie wymagało zagłębiania się przez poetę w szczegółowej dokumentacji w rodzaju Acta Martyrum czy Acta Sanctorum. Zupełnie wystarczającym źródłem mogła tutaj być tradycja ustna, którą w utworze Prudencjusza reprezentował aedituus ${ }^{7}$. Nietrudno sobie wyobrazić, że kościół, w którym znajdowały się relikwie świętego męczennika, dbał o to, aby ta tradycja była przekazywana także za pośrednictwem pielgrzymów, do których zaliczał się główny narrator utworu Prudencjusza.

Analiza Peristephanon IX pozwala stwierdzić, że właściwym źródłem inspiracji było malowidło nieznanego artysty w świątyni w Forum Cornelii przedstawiające scenę tortur św. Kasjana ${ }^{8}$. Opowiadanie kościelnego stanowi tu pewnego rodzaju rozszerzenie i uzupełnienie właściwego nucleus historii męczeństwa św.

${ }^{7}$ Opowiadanie Prudencjusza o św. Kasjanie jest najwcześniejszą relacją na temat tego męczennika; późniejsze odniesienia do św. Kasjana są mało wiarygodne z historycznego punktu widzenia. $Z$ tego powodu relacja Prudencjusza pozostaje najwcześniejszym dokumentem w Acta Sanctorum i Acta Martyrum. Na temat historycznej wartości późniejszych świadectw dotyczących św. Kasjana zob. M. La va re n n e, jw., s. 10-11, G. G ord i n i, Cassiano d'Imola. santo, martire, "Bibliotheca Sanctorum” 3(1963), s. 999-1012, A. A mor e, Cassiano d'Imola, santo, Enciclopedia Catolica, 3(1949), s. 104.

${ }^{8}$ Argumenty za istnieniem samego obrazu u M. R o be r ts a, Poetry and the Cult of the Martyrs. The liber 'Peristephanon' of Prudentius, Ann Arbor 1993, s. 139. 
Kasjana, które zostało ukazane na obrazie znajdującym się w pobliżu relikwii męczennika. Opowieść o męczeństwie św. Kasjana została skonstruowana niejako dwustopniowo: pierwszy człon stanowi ékphrasis obrazu, drugi - opowiadanie kościelnego odsłaniające szczegóły i przebieg całego wydarzenia. Bez watpienia jednak struktura Peristephanon IX dowodzi, że zasadnicza funkcja inspirująca przypadła tu samemu obrazowi w sanktuarium mieszczącym relikwie świętego męczennika. Opis malowidła pełni tu rolę prologu tego poematu, a jednocześnie jest elementem określajacym całość jego struktury. Wprowadzając motyw obrazu ilustrującego męczeństwo św. Kasjana poeta posłużył się nim jako pewnego rodzaju dokumentem potwierdzającym prawdziwość całej opowieści, jej zgodność z rzeczywistością (pictura.../veram vetusti temporis montrat fidem, w. 19-20). Pictura zawiera opowieść o męczeństwie św. Kasjana przekazaną w owych libri i wiernie odzwierciedlająca prawde o dawnym wydarzeniu. Tak więc obraz stanowi tu, jak się wydaje, prymarne źródło inspiracji całego utworu.

Inaczej przedstawia się funkcja ékphrasis obrazu w Peristephanon XI (De passione Hippolyti beatissimi martyris) ${ }^{9}$. W wierszach $125-146$ tego poematu Prudencjusz zamieścił opis obrazu, który narrator ujrzał w krypcie grobowej św. Hipolita. Było to malowidło ścienne przedstawiające zbrodnię popełnioną na męczenniku:

\section{Exemplar sceleris paries habet inlitus, in quo multicolor fucus digerit omne nefas.}

(Perist. XI 123-124)

Poeta słowami narratora opisuje obraz z natury, nie pozostawiając wątpliwości, że istotnie go widział:

Picta super tumulum species liquidis viget umbris effigians tracti membra cruenta viri.

Rorantes saxorum apices vidi, optime papa.

$$
\text { (Perist. XI 126-126) }
$$

O ile sam fakt istnienia obrazu w rzymskiej katakumbie św. Hipolita nie podlega dyskusji - w przeciwnym razie poeta nie odważyłby się pisać o nim w związku z uroczystościami ku czci męczennika ${ }^{10}$ - o tyle osoba św. Hipolita i okoliczności jego śmierci nastręczają bardzo poważne problemy. Jakkolwiek Martyrologium Hieronymianum ${ }^{11}$ kilkanaście razy wymienia imię Hipolita, to jednak wydaje się, że wszystkie odniesienia dotyczą tego samego męczennika Hipolita, którego grób przy via Tiburtina odwiedził Prudencjusz podczas swego pobytu w Rzymie. Elogium Hippolyti pióra św. Damazego, odczytane na posadzce bazyiiki Laterańskiej, gàzie zostało przeniesione $w \mathrm{XV}$ wieku z krypiy luo bazyliki św. Hipolita przy via Tiburtina, nie wspomina o rodzaju śmierci, jaką poniósł ów męczennik (martyr) ${ }^{12}$. Warto przypomnieć, że uroczystość św. Hipolita ob-

${ }^{9}$ M. R oberts, jw., s. 120 utrzymuje, że wg koncepcji Prudencjusza św. Kasjan zapłacił męczeństwem za brak w swoim nauczaniu treści etycznych, podczas gdy św. Hipolitbył schizmatykiem, którego nauka pozostawała w jawnym konflikcie z doktryną Kościoła, a jego śmierć była pewnego rodzaju karą za tę naukę.

${ }^{10}$ Por. A.-M. P a I m e r, jw., s. 250.

${ }^{11}$ Ed. G. B. de Ross i, L. D u c hes ne, AASS Nov. 2, 1, 1894, s. XLVIII-L.

${ }^{12}$ Ed. M. I h m, Anthologia Latina. Supplementum I, Lipisiae 1895, s. 42 (nr. 37 ). 
chodzono mniej więcej od połowy IV wieku w dniu $13^{13}$ sierpnia razem ze świętem ku czci św. Poncjana. Obydwaj, Hipolit i Poncjan, jako biskupi Rzymu, pozostający ze sobą w ostrym konflikcie, zostali w czasie prześladowań za panowania cesarza Maksymina Traka zesłani na Sardynię; prawdopodobnie tam doszło między nimi do pojednania. Wydaje się także, że Hipolit w czasie zesłania na Sardynię powrócił na łono Kościoła, z którego głowa papieżem Kalikstem (217-222), a później z jego następca, wspomnianym Poncjanem (230-235), wszedł w długotrwały spór, domagając się stosowania w Kościele bardziej rygorystycznych zasad wobec grzeszników i żądając osobistej świętości od osób sprawujących wysokie funkcje kościelne. Przypuszczalnie zwłoki Hipolita zostaly przywiezione do Rzymu w tym samym czasie, co i ciało Poncjanusa z Sardynii, gdzie dotychczasowi przeciwnicy mieli się przed śmiercią pojednać. Poważną trudność interpretacyjna wywołuje zawarta w epigramie św. Damazego informacja, że Hipolit był członkiem sekty Nowacjana, zawiązanej około roku 251 za pontyfikatu Korneliusza (251-253), a więc przeszło 15 lat po śmierci Hipolita męczennika. Wiadomość ta, przekazana jednak przez papieża Damazego z zastrzeżeniem, że jest ona jedynie pogłoską (fertur), została przez Prudencjusza uznana za pewną i szeroko rozwinięta w wierszach 19-38 Peristephanon XI. Ten wyraźny anachronizm, nie dostrzeżony i aprobowany przez Prudencjusza, pojawia się już na samym początku jego opowiadania o Hipolicie:

\section{Invenio Hippolytum, qui quondam quondam scisma Novati presbyter attigerat nostra sequenda negans, \\ usque ad martyrii provectum insigne tulisse lucida sanguinei praemia supplicii.}

(Perist. XI 19-22)

Główną częścią poematu o św. Hipolicie jest bez watpienia - podobnie jak w innych utworach Prudencjusza z cyklu Peristephanon - opowiadanie o męczeńskiej śmierci tytułowego bohatera. O ile w epigramie św. Damazego znajdujemy jedynie stwierdzenie, że Hipolit zasłużył na to, by zostać uznanym za męczennika (sic noster meruit confessus martyr esset, w. 7) - bez określenia okoliczności owego męczeństwa, o tyle $\mathrm{w}$ utworze Prudencjusza całe opowiadanie zostało skonstruowane wokół tego wydarzenia. Po skierowanej do hiszpańskiego biskupa Walerianusa informacji o pielgrzymce do Rzymu i o zwiedzaniu niezliczonych grobów męczenników (w. 1-16) narrator opowiada o odnalezieniu grobowca Hipolita i o jego publicznym zerwaniu przed śmiercią z sektą Nowacjana (w. 17-38). Kolejny człon poematu zawiera opowiadanie o prześladowaniach chrześcijan anonimowego prefekta rzymskiego w całym mieście, a także na wybrzeżu u ujścia Tybru (w. 39-76). Następny segment narracji ukazuje scenę sądu nad Hipolitem, wydanie nań wyroku przez okrutnego sędziego i rozerwanie skazańca przez konie (w. 77-121). Dalej znajdujemy interesującą nas ékphrasis obrazu lub raczej fresku przedstawiającego porozrzucane wśród skał i bezdroży członki męczennika, które zbieraja gorliwie jego przyjaciele (w. 122-146). Nastepne czlony narracji to opis krypty, w której zostały pochowane szczątki Hipolita (w. 147-176), osobista dygresja narratora na temat skuteczności modlitw do św. Hipolita (w. 177-182), opis

${ }^{13}$ Por. A. A mo r e, Note su Ippolito martire, „Rivista di Archeologia Cristiana” 30(1954), s. $96 \mathrm{n}$. 
kaplicy i znajdującej się w niej krypty grobowej Hipolita odwiedzanej przez pielgrzymów w dniu urodzin męczennika (w. 183-214), opis bazyliki i dorocznego święta ku czci męczennika w dniu 13 sierpnia (w. 215-238). Całość zamyka modlitwa w intencji adresata utworu, biskupa Walerianusa (w. 239-245).

Zapytajmy teraz, jaką funkcję w strukturze poematu Prudencjusza o św. Hipolicie pełni wspomniana ékphrasis obrazu w krypcie męczennika. Przede wszystkim samo nie kwestionowane istnienie obrazu ukazującego rozsiane wśród skał członki św. Hipolita dowodzi, iż znacznie przed przybyciem Prudencjusza do Rzymu zakorzeniła się tutaj tradycja, która ukształtowała legendę o śmierci męczennika wzorowaną na micie o tragicznym końcu ateńskiego bohatera Hipolita ${ }^{14}$. Po drugie, obraz przedstawiający żałosne szczątki św. Hipolita, oglądany w jego rzymskiej katakumbie, każe niejako w sposób naturalny cofnać się do początku tej historii męczeńskiej śmierci rzymskiego biskupa. Niewątpliwie u źródeł legendy o rozerwaniu biskupa Hipolita przez konie z rozkazu prefekta rzymskiego leżał klasyczny mit o synu króla Aten Tezeusza, Hipolita, który zgodnie z modlitwą oburzonego ojca został ukarany śmiercią przez Posejdona; w chwili, gdy przejeżdżał swoim rydwanem nad brzegiem morza, wynurzył się z fal potwór nasłany przez Posejdona, spłoszył konie, które wywróciły rydwan, roztrzaskały młodzieńca o przybrzeżne skały i powlokły jego ciało przez bezdroża i urwiska.

Oczywiście okoliczności związane ze śmiercią ateńskiego królewicza i chrześcijańskiego męczennika były zupełnie odmienne, tym niemniej sam rodzaj śmierci i pośmiertne losy ich ciał były dość podobne ${ }^{15}$. Wydaje się, że legenda o śmierci biskupa Hipolita została utworzona przez skojarzenie jego imienia, które oznacza „rozdarty przez konie”, z imieniem antycznego bohatera i przez przypisanie rzymskiemu biskupowi na tej podstawie takiego samego rodzaju śmierci. W samym opisie obrazu ukazującego rozwleczone przez konie członki św. Hipolita i ich pieczołowite, pełne pietyzmu zbieranie przez jego przyjaciół Prudencjusz wzorował się, jak wykazano, na podobnej scenie w Fedrze Seneki (w. $1068 \mathrm{nn}$.) ${ }^{16}$ zarówno pod względem strukturalnym, jak i językowym. Szczególnie uderzające podobieństwa między utworami Prudencjusza i Seneki widoczne są w owych scenach zbierania szczątków obydwu bohaterów; o ile jednak w tragedii Seneki towarzyszom Hipolita nie udaje się to, gdyż zostały one rozrzucone na zbyt wielkiej przestrzeni, o tyle w poemacie Prudencjusza (w. 131-146) wierni chrześcijanie $z$ powodzeniem wypełniają to zadanie. Pochowanie szczątków męczennika, które już stały się relikwiami, jest bowiem szczególnym obowiązkiem religijnym chrześcijan ${ }^{13}$.

${ }^{14}$ Por. A.-M. P a I m e r, jw., s. 250

${ }^{15}$ M. B ro że k, Aureliusz Prudencjusz Klemens, Poezje. Wstep, s. 32, uważa, że już przed Prudencjuszem, a po śmierci Damazego (384 r.) powstała legenda o rozerwaniu Hipolita przez konie; chociaż nic nie wiedziano o jego męczeńskiej śmierci, uznano go za męczennika, gdyż kojarzono jego greckie imię („Hippolytos” - rozdarty przez konie) z antycznym herosem, synem Tezeusza.

${ }^{16}$ Por. G. S ix t, Das Prudentius' Abhängikeit von Seneca und Lucan, „Philologus” 51 (1892), s. 501-506.

${ }^{17}$ Por. H. D e l h a y e, Les origines, du culte des martyrs, Brouxelles 1933, s. $120 \mathrm{n}$. 
Pozostaje jednak pytanie, czy w utworze Prudencjusza pierwotnym źródłem inspiracji był obraz-fresk znajdujący się w rzymskiej krypcie męczennika, czy tradycja dotycząca tego samego zdarzenia ukształtowana niewątpliwie w związku $z$ antycznym podaniem. Jeśli obecnie nie podaje się już w wątpliwość samego istnienia obrazu w krypcie św. Hipolita, podobnie jak obrazu męczeństwa św. Kasjana w Forum Cornelii ${ }^{18}$, sprawa kolejności owych impulsów inspiracyjnych nie wydaje się zbyt skomplikowana. O ile bowiem w Peristephanon IX opowieść o męczeństwie św. Kasjana została poprzedzona opisem obrazu, co mogłoby dowodzić, że był on istotnie źródłem inspiracji tego utworu, o tyle Peristephanon XI ma odmienną strukturę, a opis obrazu zajmuje w niej miejsce centralne i nie stanowi przedstawienia samego aktu męczeństwa, ale jego fizyczne skutki -rozproszone części ciała męczennika zbierane jako święte relikwie chrześcijańskie, które zostaną złożone w jego grobie. W tej sytuacji bardziej prawdopodobne jest przypuszczenie, że poeta w czasie zwiedzania Rzymu najpierw zapoznał się z tradycją na temat męczeńskiej śmierci Hipolita, później zaś ujrzał w krypcie grobowej świętego obraz zbierania jego szczątków.

\section{Picta imago martyris: \\ Images as the Source of Inspiration Peristephanon Hymns IX and XI by Prudentius Summary}

The author deals with hymns IX and XI from the collection Peristephanon by Prudentius. On the basis of a detailed analysis of these poems he has been able to establish that the real source of hymn IX, devoted to St. Cassianus' death at Forum Cornelium, was a painting that showed his martyrdom. As far as hymn XI, devoted to St. Hippolytus' martyrdom, is concerned it can be assumed that its original source was verbal tradition and the painting from the Roman tomb of the Saint constituted a complement for the poet.

\footnotetext{
${ }^{18}$ Dyskusja na ten temat u A.-M. P a $1 \mathrm{~m}$ e r, jw. , s. 273 nn.
} 